\title{
A research agenda to explore the role of conservation agriculture in African smallholder farming systems
}

\author{
Ken E. Giller ${ }^{\mathrm{a}, *}$, Marc Corbeels ${ }^{\mathrm{b}}$, Justice Nyamangara ${ }^{\mathrm{c}}$, Bernard Triomphe ${ }^{\mathrm{d}}$, Francois Affholder ${ }^{\mathrm{b}}$, \\ Eric Scopel ${ }^{\mathrm{b}}$, Pablo Tittonell ${ }^{\mathrm{b}}$ \\ a Plant Production Systems Group, Wageningen University, P.O. Box 430, 6700AK Wageningen, The Netherlands \\ b CIRAD UR Systèmes de Culture Annuels, 34398 Montpellier, France \\ ${ }^{\mathrm{c}}$ International Crops Research Institute for the Semi-Arid Tropics (ICRISAT), Matopos Research Station, P.O. Box 776, Bulawayo, Zimbabwe \\ d CIRAD UMR Innovation, 34398 Montpellier, France
}

\section{A R T I C L E I N F}

\section{Article history:}

Received 31 January 2011

Received in revised form 13 April 2011

Accepted 14 April 2011

\section{Keywords:}

Zero-tillage

Labour productivity

Trade-off analysis

Weed control

Innovation systems

\begin{abstract}
A B S T R A C T
Controversy surrounds the promotion of conservation agriculture (CA) in smallholder farming systems in sub-Saharan Africa. The introduction of CA is a profound change in farm management. Benefits in reduced erosion and stabilized crop production may be obtained, but technical performance at field level is but one of the determinants of adoption. For various reasons, all of the CA principles are not always fully implemented by farmers and results not as favourable as expected. As with other approaches to increasing agricultural productivity, the production constraints, farmers' objectives, and the expected benefits and costs of implementing CA are important aspects that influence adoption. At farm and village levels, trade-offs in the allocation of resources become important in determining how CA may fit into a given farming system. At a regional level, factors such as the market conditions, interactions among stakeholders and other institutional and political dimensions become important. At each level, opportunities or difficulties emerge that enhance or impede development, adaptation and adoption of CA. The ex-ante identification of situations for where CA (and which form of CA) is appropriate demands research from a multi-stakeholder, multi-level, and interdisciplinary perspective. Recommendations are made where research is required to address key knowledge gaps.
\end{abstract}

(C) 2011 Elsevier B.V. All rights reserved.

\section{Introduction}

Consensus has been reached that productivity of smallholder agriculture in Africa must increase to achieve the millennium development goals (Andriesse et al., 2007). Conservation Agriculture (CA) offers potential benefits to smallholder farmers in Africa. Avoiding the need for tillage means they can plant with the first rains and save labour, yields can be stabilized and soil erosion can be arrested (FAO, 2008). CA is based on three agronomic principles: (1) to minimize mechanical soil disturbance; (2) to maintain permanent soil cover with organic mulch; and (3) to diversify crop rotations - that need to be adapted to local conditions (FAO, 2008).

A wide variety of international organizations (e.g. FAO, CIRAD, CIMMYT, ICRISAT, the African Conservation Tillage Network) actively promote CA with smallholder farmers in Africa (Kassam et al., 2009). Yet others have highlighted that mulching can be problematic for smallholders (Erenstein, 2002, 2003), that herbicides and fertilizers are often needed to realize the benefits of CA

\footnotetext{
* Corresponding author. Tel.: +31 317 485818; fax: +31 317484892.

E-mail address: ken.giller@wur.nl (K.E. Giller).
}

but not available to smallholders (Gowing and Palmer, 2008), and that successful large-scale adoption of CA is rather rare among smallholders (Ekboir, 2003; Triomphe et al., 2007). Smallholders are reluctant to adopt CA practices if they face increased demands for labour and inputs during the first years (Affholder et al., 2010). Giller et al. (2009) questioned whether CA should be so widely promoted, and stimulated a vibrant international debate. ${ }^{1}$ The two main arguments of Giller et al. (2009) were: First, that the scientific evidence to support the claims made for CA is unclear and inconsistent, and second, that CA does not 'fit' within the majority of current smallholder farming systems in Africa.

A session of the XIth Congress of the European Society of Agronomy in Montpellier on the 29th August 2010 addressed whether Conservation Agriculture is suitable for smallholder farming in Africa with the aim of identifying research priorities for the future. Rather than using this session to rehearse previous debates on the pros and cons of CA, our intention was to explore key research issues. The aim was to highlight questions that need to be addressed

\footnotetext{
1 see http://conservationag.wordpress.com/ken-gillers-paper-on-conservationagriculture/.
} 
to derive a better understanding of whether and when CA is appropriate for smallholder farming in Africa, to search for better ways of tailoring CA to farmers' needs, and to develop an agenda to focus research. There is an urgent need for more reflection on this issue given the current emphasis on CA in the international agenda for agricultural development in sub-Saharan Africa. This short note reports on the issues highlighted in a keynote presentation (Corbeels et al., 2010) and the points raised in the ensuing panel discussion.

\section{Major issues for research}

Most of the issues identified for research are neither purely technical nor purely socioeconomic, but intertwined. For this reason we group the research questions across different integration levels (field, farm/village and region) rather than dividing into agronomic or socio-economic questions. This is a useful - though by no means perfect - way to classify the major research issues. Some issues relating to appropriate extension methods for complex crop management systems such as CA are also discussed.

\subsection{Field level - unravelling the importance of the CA principles}

CA can result in yield benefits in the long-term, but in the shortterm - and this may be up to 15 years - yield losses or no yield benefits are just as likely (Rusinamhodzi et al., 2011), especially if starting from degraded soil conditions. Benefits of CA such as saving of labour for tillage may increase profitability in the shortterm. Not all smallholder farmers use all of the three principles of CA (Gowing and Palmer, 2008), which makes the teasing out of the relative importance of management factors more than an academic exercise. Given the multiple, complex interactions between management factors that determine productivity and yield, it is not possible to address all of these simultaneously in field experiments. Crop simulation models offer a means to explore these interactive effects, but are no substitute for long-term field experiments.

As early planting is one of the main advantages of alternative land preparation methods, CA and current practice need to be compared across a range of sowing dates. Further, the effectiveness of management such as weeding is inextricably interwoven with issues relating to peak labour demand and use of herbicides. It is important that the relative needs and timing of labour are measured in experiments so that returns to labour can be calculated as an output indicator and trade-off analysis done at farm level (see Section 2.2).

A key initial question is whether or not changes in land preparation and tillage practices are the most pressing issue. Where long-term management has led to soil compaction or development of plough pans, remedial measures such as deep ripping or inversion ploughing may be needed before reduced tillage can be introduced. Thus a stepwise approach to implementation of CA may be required to overcome some of these soil physical problems.

Rotation with legumes is a key component of CA. Grain legumes are generally preferred over green manures because of their direct contribution to food or cash (Giller, 2001), although markets for legumes are often poorly developed. The question 'Which legumes best fit within the cropping systems?' needs to be answered from both technical and socioeconomic standpoints on a case by case basis.

Water conservation is regarded as one of the key attributes of CA given the erratic and unreliable rainfall in many parts of Africa. Indeed, even a small amount of mulch may have some positive effects such as enhancing infiltration of rainfall. Full water balances require detailed studies of rainfall capture (infiltration), soil storage and use by crops which necessitates detailed measurements.
A simple measure such as the rainfall productivity (as kg grain per $\mathrm{mm}$ rainfall) of CA compared with current farming methods may be a useful proxy. Simulation models can be useful for unravelling the complex interactions influencing effects of CA on water use (e.g. Scopel et al., 2004). 'Does CA enhance farmers' capacity to adapt to climate variability and climate change?', is a topical question. Studies need to explore the performance of CA across multiple seasons to capture the variability in rainfall.

Although CA is proposed as an approach to increase the productivity of smallholder agriculture, the inherent poor soil fertility prevalent in smallholder farming can also be a major constraint to implementation of CA. On the poorest soils it is difficult to produce sufficient crop residues to use as mulch, and it can be particularly problematic to achieve good production of legumes grown in rotation. Where sufficient mulch is available it is often cereal straw that may lead to problems of $\mathrm{N}$ immobilization due to the poor soil fertility especially in the initial seasons. What fertilizer rates are required to increase production and counter possible $\mathrm{N}$ immobilization by cereal residues? What are the benefits in mixing cereals with legumes? Does the efficiency of fertilizer use differ between current practice and CA? Although it may seem obvious, it is important that comparisons of CA with other practices are not confounded by use of different rates of nutrient input as is often the case.

CA is known to increase organic carbon in the surface soil (Dercon et al., 2010). CA is also often claimed to increase soil C stocks, though thorough meta-analyses report that there is an equal number of long-term experiments that show no increase (Govaerts et al., 2009; Luo et al., 2010). There is evidence that $C$ increases may be found in deeper $(>30 \mathrm{~cm}$ ) soil horizons when legumes are included in crop sequences, though the mechanisms remain unclear (Boddey et al., 2010). Many studies do not account properly for changes in stratification of soil $\mathrm{C}$ with depth and in the bulk density of the soil under reduced tillage, leading to erroneous conclusions. Soil C stocks need to be sampled taking into account changes in stratification and compared on the basis of equivalent soil mass (Ellert and Bettany, 1995). Potential environmental benefits of $C$ sequestration depend on crop productivity and are linked with $\mathrm{N}$ inputs through the use of legumes or fertilizers. Suggested impacts of CA on climate change mitigation are not obvious in the African context of low productivity, and studies need to be done under realistic farmers' conditions. The full $\mathrm{C}$ balance should also account for what happens to $C$ removed from the topsoil by erosion, and possibly transformed and sequestrated elsewhere such as in lake or marine sediments. Greenhouse gas emissions are highly variable and emission rates are influenced by residue retention, rates of fertilizer and rainfall pattern variability (Baggs et al., 2006; Metay et al., 2007; Chapuis-Lardy et al., 2009). We question 'What is the relative performance of CA compared with other management options to mitigate climate change?' - as it may not be as obvious and systematic as suggested, particularly given the poor productivity of smallholder farming.

A major benefit of CA is reduction of erosion due to the maintenance of surface mulch (Schuller et al., 2007; Pansak et al., 2008). Comparative studies with contour hedgerow systems indicate that CA can arrest erosion on moderately sloping land, though on steeper slopes hedgerows or grass contour strips might be necessary, as mulch can be washed away during heavy rains leaving the soil unprotected against erosion (Pansak et al., 2008; Guto, 2011). The relative functions of living barriers, mulch for soil cover or tillage for increased soil roughness in enhancing infiltration and thus reducing runoff and soil erosion require further investigation, and this for a range of soil types and slopes.

A key question relating to all of the above functions of mulch is 'What proportion of the crop residues can be removed?' or conversely, 'What is the minimum amount of crop residues required to 
provide the benefits of mulching?'. Understanding the thresholds in terms of the amount of mulch needed to support different ecological functions would help to define the flexibility for farmers to remove biomass for other purposes.

\subsection{Farm, village and regional level - CA within the context and conditions of African smallholders}

Labour availability and demands vary enormously among farmers, depending on whether they have access to draught power for tillage and weeding, and herbicides. In some African countries there is a risk of shifting much labour from men (who traditionally take care of tillage) to women (who take care of weeding) (Baudron et al., 2007; Giller et al., 2009). The relative labour constraints of farmers of different resource endowment require further investigation, particularly in relation to times of peak labour demand within the cropping season. Returns to labour can then be calculated as an output indicator in addition to returns to land. The economic impacts of labour use for tillage, weeding, and inputs of fertilizer and herbicide need to be assessed in relation to the benefits for production at farm scale.

In southern Africa, a practice termed conservation farming has been actively promoted. Conservation farming involves digging planting basins using hand hoes and retention of crop residues as mulch (Mazvimavi and Twomlow, 2009). Reduced tillage using oxdrawn 'rippers' was also promoted. In line with policies of donor organizations, the most vulnerable and resource-constrained have been targeted. The major positive impact of using planting basins is the ability to plant with the first rains, and thereby to benefit from the high temperatures and the mineral $\mathrm{N}$ flush at the start of the season. The basins also encourage controlled plant densities and precise placement of mineral and organic fertilizer. Although digging of planting basins appears to be a practical and easily accessible option for poorer farmers, such people often need to work for other farmers to earn income and food. The opportunities within the local labour market often coincide with peak periods of labour demand in their own farms, leading to delays in operations and the yield penalty that this incurs. The area of land prepared with planting basins has remained stagnant (ca. 0.2 ha per farm) mainly due to labour constraints (pits which are destroyed during the dry season, weeding as herbicides were not available) (Mazvimavi and Twomlow, 2009). Poorer farmers have some of the most degraded fields, due to repeated cultivation with little or no inputs, are more risk-averse and thus less able to try out new approaches.

Smallholder farmers often attribute more value to immediate costs and benefits than those incurred or realised in the future, due to the constraints of production and food security that they face. Savings in labour due to reduced or zero tillage may be immediate, but not tilling may create greater demand for labour at weeding or for herbicide. Many other benefits of CA are only realised in the longer term. Trade-off analysis can be done using bio-economic household models (e.g. Affholder et al., 2010) or with biophysical dynamic simulation models coupled with optimisation algorithms and objective functions representing farmers' priorities (Tittonell et al., 2007).

A deeper understanding of how farmers prioritize the competing uses for crop residues (e.g. for mulch, livestock feed, as fuel or for construction) is required. In most farming systems there is a large diversity in livestock ownership, with some farmers owning livestock and others none. The competition between residues for mulch or for livestock feed is most apparent in systems where livestock are released to graze freely after crop harvest. Under such conditions fencing or changes in grazing by-laws would be required to allow sufficient residue retention. Even where livestock are kept in stalls throughout the year (zero-grazing), crop residues are often harvested and kept for feeding animals during the dry season. Poorer

\section{Likelihood of adoption by farmers?}

\begin{tabular}{lll}
\hline - Flat land & - Steep slopes \\
- Sandy/loam soils & - Clayey soils \\
- Poor productivity & - Abundant biomass \\
- Many livestock & - Few livestock \\
- Little capacity to & - Wealthier farmers \\
invest & who can afford inputs \\
- Farmers with little & - Farmers with \\
inputs & & experience of cash- \\
- Insecure land tenure & - Secure land tenure \\
- Large land holdings & - Small land holdings \\
- Poor markets & - Good markets \\
- Poor institutional & - 'Enabling' institutional \\
environment & & environment
\end{tabular}

Fig. 1. Conditions likely to favour adoption of conservation agriculture by smallholder farmers in Africa. Several of these factors are interlinked and may interact.

farmers often sell their residues to livestock keepers (Guto, 2011). In general, it seems that livestock feed is prioritized above other uses and that even the crop residues from farms that have few or no livestock end up being grazed in their fields or sold as feed. The promotion of CA has to be done along with the development of improved methods of feeding, including the use of forage crops. Integration of CA within farming systems needs to address the need for livestock feed, and indeed rotations with forage crops, ley-arable systems or integration with legume fodder trees may offer opportunities to develop new reduced tillage approaches. Land access issues and competing uses for crop residues among different types of farmers also require analysis at the village level (Rufino et al., 2011), at which negotiations for land use and resource allocation take place. An action-research approach offers the opportunity to actively test and develop alternative arrangements, going beyond assessment and understanding of the current situation. It is often when trying to change arrangements that an understanding of the current situation is gained (Faure et al., 2010). A better understanding of the sociotechnical and organizational issues is required. A central question is "When and for whom CA is likely to be more suited?' - some suggestions are given in Fig. 1.

The availability and use of inputs such as seed, fertilizer and herbicides or implements for reduced tillage (such as jab-planters, oxor donkey-drawn rippers) depends on the development of infrastructure for agricultural support through local agro-dealer shops and implement hiring services. The same applies to farmers' access to credit and to markets for agricultural inputs and produce. In many regions, development of better markets for grain legumes is needed before farmers can invest in more balanced cereal-legume rotations. Even when cost-benefit analysis at farm level indicates economic benefits, farmers may lack the opportunity to purchase inputs ahead of the cropping season, or lack the cash to invest. A richer understanding would assist identification of the institutional support required to enable farmers to invest in CA if they wish to.

\subsection{Approaches to the innovation process and measuring adoption}

Given the need to tailor CA practices to local conditions, and the complexity and knowledge-intensive nature of CA systems (Giller et al., 2009; Ekboir, 2003; Triomphe et al., 2007), a strong capacity in problem-solving among farmers, development agents and researchers is required. Given that CA involves a substan- 
tial change in farming practices, what are the most appropriate approaches to nurture a meaningful CA innovation process, including capacity-strengthening of key stakeholders and appropriate dissemination strategies? Farmers adapt and implement new technologies with their own understanding and interpretation of the underlying principles and rationale, their own priorities and the possibilities to integrate new approaches into their farming systems. The active participation of farmers in iterative technology development through action research to facilitate co-learning and co-innovation, may be a promising approach, as has been shown to foster the adoption of soil improving technologies (e.g. Misiko and Tittonell, 2009). In doing so, use of an innovation systems perspective is needed to tackle the challenges of complex management systems, as illustrated by the documented successes of CA around the world that have involved a wide range of actors including private companies and governments (Ekboir, 2003).

A better understanding of the contrasting innovation and adoption dynamics of CA between, on the one-hand, the successes in South Asia (the rice-wheat systems in the Indo-Gangetic Plain) and in large-scale farms of Latin America (Argentina, Brazil and Paraguay), and on the other hand the difficulties encountered in Europe and Africa, could provide useful lessons to guide research and investments. What factors influenced both technical performance and farmers' adoption? To what extent, how and why have smallholders been involved?

From many reports it is not clear what is taken to constitute 'adoption' of CA in Africa (and in some cases what is taken to constitute (A). CA has often been promoted as part of a full package including fertilizers and herbicides, so that farmers' interest in CA may be partly due to the increased access to inputs rather than the change in tillage practices per se. Many reports of farmer adoption are made while projects are actively promoting CA and adoption figures may simply reflect the number of farmers involved in testing and adapting the technologies. More intense follow up is required in localities where interventions have ceased to reveal what different practices are continued after projects end. In South Africa, only few farmers could be identified who continued to use CA techniques that they had learned about (e.g. Bolliger, 2007). Further detailed studies using both quantitative and qualitative methods are required to learn about the reasons for farmers 'dis-adoption' (cf. Neill and Lee, 2001) and inform those planning development interventions.

\section{Conclusions}

The research community concerned with CA is faced with a number of quandaries. Research on experimental stations is not particularly relevant because it does not mimic sufficiently farmers' agroecological (and notably soil) conditions. But long-term approaches are required to account for the influence of different seasons and to explore effects that may take several years to become apparent, such as changes in soil C stocks. Nor do agronomic experiments take account of the important and numerous interactions between agronomic and socioeconomic issues. A wealth of expert knowledge exists among CA practitioners worldwide. Much could be gained by measuring and documenting impacts of CA in practice and critically evaluating these experiences with rigorous peer-review.

Research into management options needs to recognize the wide diversity of farmers in terms of resource endowments, and farming systems, and the broader institutional and policy environment within which they are embedded. Understanding of farmers' priorities and constraints is needed to drive research on appropriate technologies at field level. Thus research needs to develop an integrative, interdisciplinary and participatory character. This will allow an understanding of whether CA is an attractive option for farmers. Much more attention needs to be given to the testing, tailoring and targeting of the relevant components of CA across the diverse agro-ecological and socio-economic conditions of different countries.

Overall, experience with CA in sub-Saharan Africa and elsewhere across a range of socio-ecological circumstances reveals that no blueprint or silver bullet exists, and dogmas or rigid prescriptions are inappropriate. Many of the issues raised in this discussion are not peculiar to CA but relevant to most approaches to increasing productivity of smallholder farming. These emerging research issues will help to shape our understanding of when and whether local adaptation of CA principles may be an appropriate way to address the needs of smallholder farmers. Knowledge of complementarities that exist with other approaches to enhancing farmers' livelihoods will allow research to make a fuller contribution to agricultural development in Africa.

\section{Acknowledgements}

We thank the organizers of ESA2010, and in particular Jacques Wery, for the opportunity of organizing the symposium that formed the basis of this contribution. Gerd Dercon and Michael Jenrich made important contributions to the panel discussion in Montpellier and extensive comments on earlier manuscripts that helped to shape the text. Marc Corbeels, Bernard Triomphe, Eric Scopel and Pablo Tittonell are funded by the European Commission through the CA2Africa project.

\section{References}

Affholder, F., Jourdain, D., Quang, D.D., Tuong, T.P., Morize, M., Ricome, A., 2010. Constraints to farmers' adoption of direct-seeding mulch-based cropping systems: A farm scale modelling approach applied to the mountainous slopes of Vietnam. Agric. Syst. 103, 51-62.

Andriesse, W., Giller, K.E., Jiggins, J., Löffler, H., Oosterveer, P., Woodhill, J., 2007. The Role of Agriculture in Achieving MDG1-A Review of the Leading Reports. Wageningen International, Wageningen.

Baggs, E.M., Chebii, J., Ndufa, J.K., 2006. A short-term investigation of trace gas emissions following tillage and no-tillage of agroforestry residues in western Kenya. Soil Till. Res. 90, 69-76.

Baudron, F., Mwanza, H.M., Triomphe, B., Bwalya, M., 2007. Conservation Agriculture in Zambia: A Case Study of Southern Province. Conservation Agriculture in Africa Series. African Conservation Tillage Network, Centre de Coopeřration Internationale de Recherche Agronomique pour le Deřveloppement, Food and Agriculture Organization of the United Nations, Nairobi, Montpellier, Rome.

Boddey, R.M., Jantalia, C.P., Conceicao, P.C., Zanatta, J.A., Bayer, C., Mielniczuk, J., Dieckow, J., Dos Santos, H.P., Denardin, J.E., Aita, C., Giacomini, S.J., Alves, B.J.R. Urquiaga, S., 2010. Carbon accumulation at depth in Ferralsols under zero-till subtropical agriculture. Glob. Change Biol. 16, 784-795.

Bolliger, A., 2007. Is Zero-till an Appropriate Agricultural Alternatiive for Disadvantaged Smallholders of South Africa? A Study of Surrogate Systems and Strategies, Smallholder Sensitivities and Soil Glycoproteins. University of Copenhagen, Copenhagen, p. 67.

Chapuis-Lardy, L., Metay, A., Martinet, M., Rabenarivo, M., Toucet, J., Douzet, J.M. Razafimbelo, T., Rabeharisoa, L., Rakotoarisoa, J., 2009. Nitrous oxide fluxes from Malagasy agricultural soils. Geoderma 148, 421-427.

Corbeels, M., Triomphe, B., Tittonell, P., Affholder, F., Lahmar, R., Scopel, E., Alary, V. Jourdain, D., 2010. Tailoring conservation agriculture to local contexts and conditions of smallholder farmers in Africa. In: Wery, J., Shili-Touzi, I., Perrin, A. (Eds.), Proceedings of Agro2010-the XIth ESA Congress. August 29th-September 3rd, 2010, Montpellier, France. Agropolis International Editions, Montpellier, France, pp. 37-38.

Dercon, G., Nguyen, M.L., Aulakh, M., Boddey, R., Dalal, R., Govaerts, B., Halitligil, M., Ibragimov, N., Ismaili, M., Lopez, S., Mohammad, W., Pulleman, M., Vanlauwe, B., Zagal, E., 2010. Soil, water and nutrient management under conservation agriculture across agro-ecosystems worldwide: an overview of main lessons learnt under an FAO/IAEA coordinated research project. In: Wery, J., Shili-Touzi, I., Perrin, A. (Eds.), Proceedings of Agro2010-The XIth ESA Congress. August 29th-September 3rd, 2010, Montpellier, France. Agropolis International Editions, Montpellier, France, pp. 437-438.

Ekboir, J.M., 2003. Research and technology policies in innovation systems: zero tillage in Brazil. Res. Policy 32, 573-586.

Ellert, B.H., Bettany, J.R., 1995. Calculation of organic matter and nutrients stored in soils under contrasting management regimes. Can. J. Soil Sci. 75, 529-538. 
Erenstein, O., 2002. Crop residue mulching in tropical and semi-tropical countries: an evaluation of residue availability and other technological implications. Soil Till. Res. 67, 115-133.

Erenstein, O., 2003. Smallholder conservation farming in the tropics and sub-tropics: a guide to the development and dissemination of mulching with crop residues and cover crops. Agric. Ecosyst. Environ. 100, 17-37.

FAO, 2008. Investing in Sustainable Agricultural Intensification. The Role of Conservation Agriculture. A Framework for Action. Food and Agriculture Organization of the United Nations, Rome.

Faure, G., Gasselin, P., Triomphe, B., Hocdé, H., Temple, L., 2010. Innover avec les acteurs du monde rural: la recherche-action en partenariat. (Innovate with rural stakeholders: action-research in partnership) Ed. Quae, Versailles.

Giller, K.E., 2001. Nitrogen Fixation in Tropical Cropping Systems. CAB International, Wallingford.

Giller, K.E., Witter, E., Corbeels, M., Tittonell, P., 2009. Conservation agriculture and smallholder farming in Africa: the heretics' view. Field Crop. Res. 114, 23-34.

Govaerts, B., Verhulst, N., Castellanos-Navarrete, A., Sayre, K.D., Dixon, J., Dendooven, L., 2009. Conservation agriculture and soil carbon sequestration: between myth and farmer reality. Crit. Rev. Plant Sci. 28, 97-122.

Gowing, J.W., Palmer, M., 2008. Sustainable agricultural development in subSaharan Africa: the case for a paradigm shift in land husbandry. Soil Use Manage. 24, 92-99.

Guto, S.N., 2011. Chakula Bila Kulima? Trade-offs Concerning Soil and Water Conservation in Heterogeneous Smallholder Farms of Central Kenya. Wageningen University, Wageningen.

Kassam, A., Friedrich, T., Shaxson, F., Pretty, J., 2009. The spread of conservation agriculture: justification, sustainability and uptake. Int. J. Agric. Sust. 7, 292-320.

Luo, Z., Wang, E., Sun, O.J., 2010. Can no-tillage stimulate carbon sequestration in agricultural soils? A meta-analysis of paired experiments. Agric. Ecosyst. Environ. 139, 224-231.

Mazvimavi, K., Twomlow, S., 2009. Socioeconomic and institutional factors influencing adoption of conservation farming by vulnerable households in Zimbabwe. Agric. Syst. 101, 20-29.

Metay, A., Oliver, R., Scopel, E., Douzet, J.M., Alves Moreira, J.A., Maraux, F., Feigl, B.J., Feller, C., 2007. $\mathrm{N}_{2} \mathrm{O}$ and $\mathrm{CH}_{4}$ emissions from soils under conventional and no-till management practices in Goiania (Cerrados, Brazil). Geoderma 141 78-88.

Misiko, M., Tittonell, P., 2009. Counting eggs? Smallholder experiments and tryouts as success indicators of adoption of soil fertility technologies. In: Bationo, A., Waswa, B.S., Okeyo, J.M., Maina, F. (Eds.), Innovations as key to the Green Revolution in Africa: Exploring the Scientific Facts. Springer, New York.

Neill, S.P., Lee, D.R., 2001. Explaining the adoption and disadoption of sustainable agriculture: the case of cover crops in northern Honduras. Econ. Dev. Cult. Change 49, 793-820.

Pansak, W., Hilger, T.H., Dercon, G., Kongkaew, T., Cadisch, G., 2008. Changes in the relationship between soil erosion and $\mathrm{N}$ loss pathways after establishing soil conservation systems in uplands of Northeast Thailand. Agric. Ecosyst. Environ. $128,167-176$.

Rufino, M.C., Dury, J., Tittonell, P., van Wijk, M.T., Herrero, M., Zingore, S., Mapfumo, P., Giller, K.E., 2011. Competing use of organic resources, village-level interactions between farm types and climate variability in a communal area of NE Zimbabwe. Agric. Syst. 104, 175-190.

Rusinamhodzi, L., Corbeels, M., van Wijk, M., Rufino, M.C., Nyamangara, J., Giller, K.E., 2011. Long-term effects of conservation agriculture practices on maize yields under rain-fed conditions: lessons for southern Africa. Agron. Sust. Dev. in press.

Schuller, P., Walling, D.E., Sepulveda, A., Castillo, A., Pino, I., 2007. Changes in soil erosion associated with the shift from conventional tillage to a no-tillage system, documented using ${ }^{137}$ Cs measurements. Soil Till. Res. 94, 183-192.

Scopel, E. Da Silva, F., Corbeels, M., Affholder, F, Maraux, F., 2004. Modelling crop residue mulching effects on water use and production of maize under semi-arid and humid tropical conditions. Agronomie 24, 383-395.

Tittonell, P., van Wijk, M.T., Rufino, M.C., Vrugt, J.A., Giller, K.E., 2007. Analysing trade-offs in resource and labour allocation by smallholder farmers using inverse modelling techniques: A case-study from Kakamega district, western Kenya. Agric. Syst. 95, 76-95.

Triomphe, B., Goudet, F., Dreyfus, F. de Tourdonnet, S., 2007. Du labour au nonlabour: Pratiques, Innovations \& Enjeux au Sud et au Nord. In: Bourrigaud, R. Siguat, F. (Eds.), Nous labourons. Actes du colloque "Techniques de travail de la terre, hier et aujourd'hui, ici et là-bas". Centre Histoire Travail, Nantes, pp. 371-384. 